Gut, 1973, 14, 956-961

\title{
The effect of phenobarbital on cholesterol gallstones in hamsters
}

\author{
JUAN LAGARRIGA AND IAN A. D. BOUCHIER \\ From the Department of Medicine, Royal Free Hospital, London
}

SUMMARY This experimental study was undertaken to follow the influence of phenobarbital on bile chemistry and gallstone formation. Phenobarbital $(400 \mathrm{mg} / \mathrm{kg} / \mathrm{day})$ was administered to golden hamsters receiving a diet known to induce cholesterol gallstones. After a 28-day period none of the control animals had gallstones whereas five of 12 animals with added phenobarbital developed stones. Ten of 19 animals on the lithogenic diet formed gallstones but when phenobarbital was added gallstones occurred in 16 of 19 hamsters. The administration of phenobarbital resulted in the production of bile which was relatively more saturated with cholesterol, the bile salt + phospholipid: cholesterol of $24.8 \pm 12.7$ in control animals altering to $9 \cdot 1 \pm 6.2$ in animals receiving phenobarbital. Hepatic bilirubin uridine diphosphate-glucuronyl transferase activity was not increased in animals on phenobarbital. It was concluded that, in the hamster at least, there is no indication that large doses of phenobarbital will reduce the potential for gallstone formation.

Most of the current evidence indicates that cholesterol gallstones are formed when the ratio of bile acids and phospholipids to cholesterol falls below a critical level. The bile becomes saturated with respect to cholesterol which precipitates out of solution as crystals. These eventually coalesce to form stones (Admirand and Small, 1968; Bouchier, 1971b). An increase in cholesterol secretion (Grundy, Metzger, and Adler, 1972), or a decrease in bile salt secretion (Vlahcevic, Bell, Buhac, Farrar, and Swell, 1970; Danzinger, Hofmann, Schoenfield, and Thistle, 1971), or a combination of these two events could be the cause of this phenomenon. On the other hand, an increase in the ratio bile salt + phospholipid : cholesterol enhances the cholesterol-holding capacity of bile. Manipulation of bile chemistry in this way has relevance to the introduction of pharmacological methods for human gallstone dissolution (Danzinger, Hofmann, Schoenfield, and Thistle, 1972: Bell, Whitney, and Dowling, 1972).

Preliminary reports suggest a dual enzymatic defect in human gallstone disease, namely, an enhanced activity in 3-hydroxy-3-methylglutamyl CoA reductase (HMG CoA reductase) which results in

${ }^{1}$ Please address correspondence to: Professor Ian A. D. Bouchier, Department of Medicine, University of Dundee, Dundee, DD1 4HN.

Received for publication 25 September 1973. an increase in cholesterol biosynthesis, and a reduced activity in the 7 alpha hydroxylation of cholesterol with a consequent induction in bile salt synthesis (Nicolau, Shefer, Salen, and Mosbach, 1973). Phenobarbital is a well known microsomal enzyme inducer (Conney, 1967), which is capable of increasing the activity of both enzymes (Wada, Hirata, and Sakamoto, 1967; Wada, Hirata, Nakao, and Sakamoto, 1968; Shefer, Hauser, and Mosbach, 1972). In a number of animal species, the biosynthesis of cholesterol (Jones and Armstrong, 1965; Wada et al, 1967; Orrenius, Das, and Gnosspelius, 1969; Schoenfield, Rupprect, and Bonorris, 1973), bile salts (Schoenfield, et al, 1973; Redinger and Small, 1973), and phospholipids (Japunžić, Mimić-oka, and Japundzic, 1971; Young, Powell, and McMillan, 1971) is increased as a result of phenobarbital treatment. Furthermore, there is evidence in the monkey that this drug alters hepatic metabolism in such a way that bile less saturated with cholesterol is produced (Redinger and Small, 1973). These observations have led to the suggestion that phenobarbital might be used in the prevention and treatment of human gallstone disease.

The hamster is a useful animal for the study of human gallstone disease because cholesterol gallstones can be readily induced by dietary manipulation (Dam, 1971). Animals forming gallstones have alterations in bile composition similar to that 
seen in man (Bouchier, 1971a). The present investigation was undertaken in an attempt to evaluate the influence of phenobarbital administration on the development of gallstones in hamsters. The results indicate that phenobarbital is ineffective in preventing gallstone formation.

\section{Materials and Methods}

Seventy male golden hamsters (Cricetus aureatus), aged 5 weeks and weighing 48 to $66 \mathrm{~g}$ were used. For the first week the animals were placed on a normal stock diet and protected from exposure to materials known to induce hepatic microsomal enzymes (Fouts and Gram, 1969). After this period they were divided into four groups with a similar weight range and fed according to the following scheme:

GROUP A

Twelve hamsters on normal chow diet (41B modified diet, Oxoid, London)

GROUP B

Twenty-four hamsters on the lithogenic diet

GROUP C

Twelve hamsters on the normal diet but with a $1 \mathrm{mg} / \mathrm{ml}$ sodium phenobarbital solution instead of drinking water

GROUP D

Twenty-four hamsters on the lithogenic diet but with a $1 \mathrm{mg} / \mathrm{ml}$ sodium phenobarbital solution instead of drinking water.

The lithogenic diet was essentially similar to that described by Dam and Christensen (1962), with the exception that vitamins were included in the following amounts for each $100 \mathrm{mg}$ of diet: alpha tocopherol, $20 \mathrm{mg}$; synkavit, $10 \mathrm{mg}$; A, $2000 \mathrm{IU}$; D, $2000 \mathrm{IU} ; \mathrm{B}_{1}, 0.5 \mathrm{mg}$; $\mathrm{B}_{2}, 0.2 \mathrm{mg}$; $\mathrm{B}_{6} 0.5 \mathrm{mg}$; nicotinic acid, $5 \mathrm{mg}$; and ascorbic acid, $50 \mathrm{mg}$.

The animals were housed three in a cage and all had free access to food and drink. Animals receiving phenobarbital drank the same amount of water as animals not on the drug. Each hamster received a dose of $400 \mathrm{mg}$ phenobarbital $/ \mathrm{kg} / \mathrm{day}$. At the end of 28 days a laparotomy was performed under ether anaesthesia, the cystic duct ligated, and the liver and gallbladder were removed.

\section{Gallstones}

The presence of gallstones was determined by visual examination of the gallbladder. Animals were graded as follows: $\mathrm{O}$, no gallstones detected; + , less than five stones; and ++ , five or more stones.
Because of the thin gallbladder wall in the hamster it was possible to make this evaluation without opening the gallbladder.

\section{Bile Analysis}

The fundus of the gallbladder was incised and the total contents washed into a tube using distilled water. Aliquots of this diluted bile were removed for duplicate extraction of phospholipids and cholesterol using the method of Folch, Lees, and Sloane-Stanley (1957). The phosphorous content of the extract was estimated by the method of King (1932), and the molar concentration of phospholipids was calculated assuming one atom of phosphorus per molecule. The cholesterol content of the extract was estimated using the method of Zlatkis, Zak, and Boyle (1953). The upper phase plus washings from the extraction were assayed in duplicate for total bile acids using the steroid dehydrogenase method of Iwata and Yamasaki (1964). Since the dilution factor for the gallbladder content was unknown, bile composition was expressed as the molar percentage of these three components.

In preliminary studies gallstones were carefully removed from the gallbladders of animals from each of the experimental groups. The stones were washed in water and extracted with chloroform. Lipid separation using thin-layer chromatography was performed with the solvent system heptane-etherglacial acetic acid $(60: 40: 1, \mathrm{v} / \mathrm{v})$.

\section{Enzyme Estimation}

Immediately following hepatectomy, the liver was dried and weighed, and 1 gram was homogenized with $10 \mathrm{ml}$ of $250 \mathrm{mM}$ sucrose in $1 \mathrm{mM}$ EDTA (pH 7.4) cooled to $6^{\circ} \mathrm{C}$. Ten $\mathrm{ml}$ of an aqueous digitonin suspension $(2 \% \mathrm{w} / \mathrm{v})$ was added and the preparation stored at $-4^{\circ} \mathrm{C}$ for less than 48 hours. Aliquots of the homogenate with digitonin were assayed in duplicate for bilirubin uridine diphosphate-glucuronyl transferase (UDPGtase) as described by Black, Billing, and Heirwegh (1970). Unconjugated bilirubin was used as a substrate. The diazo-reaction was undertaken at room temperature, in the dark. All the estimations were performed simultaneously with a pretested sample as an index. The differences in values between the duplicates was less than $10 \%$.

\section{Statistical Methods}

For all experimental groups, sample means and standard errors of the mean were calculated. Differences between two groups were assessed for 
statistical significance by Student's $t$ test. The statistical significance for the incidence of stones between groups $B$ and $D$ was assessed using chi square with Yate's correction (Bailey, 1959).

\section{Results}

Five animals from each of the groups $B$ and $D$ died before the end of the experiment and were omitted from the final evaluation. Of these, two, both from group D, had gallstones.

Animals in groups B and D which were on the lithogenic diet lost weight (final weight $49+8.4 \mathrm{~g}$ and $49 \pm 6.6 \mathrm{~g}$ respectively) whereas the animals in groups $A$ and $C$, receiving the chow diet, gained weight (final weight $85.9 \pm 11 \mathrm{~g}$ and $79 \pm 11.2 \mathrm{~g}$ respectively).

The incidence of gallstones in the group is given

\begin{tabular}{|c|c|c|c|c|}
\hline \multirow[t]{2}{*}{ Group $^{1}$} & \multirow[t]{2}{*}{ No. of Animals } & \multicolumn{3}{|c|}{ Quantity of Gallstones ${ }^{2}$} \\
\hline & & $O$ & + & ++ \\
\hline $\begin{array}{l}\text { A } \\
\text { Control diet }\end{array}$ & 12 & 12 & 0 & $\mathbf{0}$ \\
\hline $\begin{array}{l}\text { B } \\
\text { Lithogenic diet }\end{array}$ & 19 & 9 & 6 & 4 \\
\hline $\begin{array}{l}\text { C } \\
\text { Control }+ \\
\text { phenobarb }\end{array}$ & 12 & 7 & 5 & 0 \\
\hline $\begin{array}{l}\text { D } \\
\text { Lithogenic + } \\
\text { phenobarb }\end{array}$ & 19 & 3 & 5 & 11 \\
\hline
\end{tabular}

Table I The effect of phenobarbital on the incidence of gallstones in hamsters fed a lithogenic diet.

'See text for explanation of groups.

${ }^{2} 0=$ no stones, $+=$ less than five stones, $++=$ five or more stones. in table I. No gallstones were present in the control group A. Ten of the 19 animals in group B (52.6\%) developed gallstones as did five out of 12 from group C $(41.6 \%)$. Sixteen of the 19 animals in group D $(84.2 \%)$ developed gallstones which was a significantly increased incidence compared with group B (chi square $\mathbf{P}=<0.05$ ). Not only did a greater number of animals develop gallstones but, as can be seen from table I, the quantity of the stones was larger in those animals on the lithogenic diet that received phenobarbital in addition.

The presence of cholesterol in the gallstones was demonstrated by thin-layer chromatography of the extracts.

Table II summarizes the results of the changes observed in the bile and liver of animals studied. There was a significant increase in the ratio liver weight : body weight in all groups compared with group A. The activity of UDPGtase was significantly decreased in animals receiving the lithogenic diet alone $(P<0.0025)$. The slight increase in enzyme activity noted in groups $\mathrm{C}$ and $\mathrm{D}$ did not reach statistical significance.

The animals from groups B, C, and D all differed from the control $A$ in having significantly lowered bile salt + phospholipid : cholesterol ratios: $14 \cdot 5$, $8 \cdot 3$, and $9 \cdot 1$ respectively. There was a decrease in the molar percentage of bile salt and an increase in the molar percentage of phospholipids and cholesterol. The increase in cholesterol was relatively greater than in the increase in phospholipids as shown in table II. Groups C and D did not differ significantly from each other in any respect. The effect of either the lithogenic diet and/or the administration of phenobarbital was the production of a bile which was more saturated with cholesterol.

\begin{tabular}{|c|c|c|c|c|c|c|}
\hline Group & $\begin{array}{l}\text { Ratio Liver Weight }{ }^{1} \\
\text { Body Weight }\end{array}$ & $\begin{array}{l}\text { UDPGtase } \\
\text { (mg of conjugated } \\
\text { bilirubin/g/hour) }\end{array}$ & $\begin{array}{l}\text { Bile Salts + Phospholipids } \\
\text { Cholesterol }\end{array}$ & $\begin{array}{l}\text { Bile Salts } \\
(\%)\end{array}$ & $\begin{array}{l}\text { Phospholipids } \\
\text { (\%) }\end{array}$ & $\begin{array}{l}\text { Cholesterol } \\
(\%)\end{array}$ \\
\hline $\begin{array}{l}\text { A Control } \\
\text { diet }\end{array}$ & $\begin{array}{l}5.6 \pm 0.5 \\
(12)\end{array}$ & $\begin{array}{l}887 \\
(12)\end{array}$ & $\begin{array}{l}24 \cdot 8 \pm 12 \cdot 7 \\
(10)\end{array}$ & $\begin{array}{l}85.7 \\
(10)\end{array}$ & $\begin{array}{l}9.5 \pm 3.9 \\
(10)\end{array}$ & $\begin{array}{l}4 \cdot 8 \pm 2 \cdot 4 \\
(10)\end{array}$ \\
\hline $\begin{array}{l}\text { B } \\
\text { Lithogenic } \\
\text { diet }\end{array}$ & $\begin{array}{l}7 \cdot 8 \pm 2 \cdot 0^{3} \\
(19)\end{array}$ & $\begin{array}{l}598 \pm 227^{3} \\
(19)\end{array}$ & $\begin{array}{l}14 \pm 17 \cdot 2^{2} \\
(16)\end{array}$ & $\begin{array}{l}76 \cdot 2 \pm 7 \cdot 2 \\
(16)\end{array}$ & $\begin{array}{l}13 \cdot 3 \pm 4 \cdot 0 \\
(16)\end{array}$ & $\begin{array}{l}10 \cdot 2 \pm 4 \cdot 3 \\
(16)\end{array}$ \\
\hline $\begin{array}{l}\text { C } \\
\text { Control }+ \\
\text { phenobarb }\end{array}$ & $\begin{array}{l}7 \cdot 2 \pm 1 \cdot 3^{2} \\
(12)\end{array}$ & $\begin{array}{l}1038 \pm 448^{\mathrm{Ns}} \\
(12)\end{array}$ & $\begin{array}{l}8 \cdot 3 \pm 5 \cdot 64 \\
(11)\end{array}$ & $\begin{array}{l}64 \cdot 8 \pm 8 \cdot 0 \\
\text { (11) }\end{array}$ & $\begin{array}{l}22 \cdot 5 \pm 7.0 \\
(11)\end{array}$ & $\begin{array}{l}12 \cdot 9 \pm 4 \cdot 1 \\
(11)\end{array}$ \\
\hline $\begin{array}{l}\text { D } \\
\text { Lithogenic }+ \\
\text { phenobarb }\end{array}$ & $\begin{array}{l}6 \cdot 6 \pm 2 \cdot 3^{3} \\
(19)\end{array}$ & $\begin{array}{l}938 \pm 590^{\mathrm{Ns}} \\
(19)\end{array}$ & $\underset{(17)}{9 \cdot 1} \pm 6 \cdot 2^{4}$ & $\begin{array}{l}74 \cdot 7 \pm(6) \\
(17)\end{array}$ & $\begin{array}{l}12 \cdot 8 \pm 2 \cdot 3 \\
(17)\end{array}$ & $\begin{array}{l}12 \cdot 4 \pm 4 \cdot 9 \\
(17)\end{array}$ \\
\hline
\end{tabular}

Table II Biochemical changes in hamsters on a lithogenic diet with and without added phenobarbital

${ }^{1}$ Results shown as mean $\pm \mathrm{SD}$. Figures in brackets indicate number of animals studied.

All groups are compared with group $\mathbf{A}$.

${ }^{2} \mathbf{P}=<0.01$

${ }^{3} \mathbf{p}=<0.0025$

${ }^{4} P=<0.0005$

NS $=$ not significant. 


\section{Discussion}

The results of this study indicate that phenobarbital did not prevent the induction of gallstones in hamsters on the lithogenic diet described by Dam and Christensen (1962). Indeed, there is evidence that the tendency to gallstone formation was enhanced. Furthermore, animals receiving a normal chow diet with added phenobarbital developed cholesterol gallstones. These animals all gained weight and appeared healthy, therefore it seems unlikely that other nutritional factors were responsible for the formation of gallstones which accompanied the administration of phenobarbital.

In keeping with the development of cholesterol gallstones in the hamsters is the observation that the bile became more saturated with cholesterol. There was a relative reduction in the molar percentage of bile salts and an increase in cholesterol. This was reflected in the bile salt + phospholipid : cholesterol ratio which altered from 24.8 in control animals to $\mathbf{9 \cdot 1}$ and 14.5 in the test animals. These observations are in contrast with the preliminary report of Schoenfield et al (1973) who found that the administration of phenobarbital to hamsters stimulated hepatic bile acid and to a lesser extent cholesterol synthesis which led the authors to believe that phenobarbital might alter bile composition favourably with regard to cholesterol solubility.

Phenobarbital is a choleretic drug in several species (Roberts and Plaa, 1967; Plaa, 1968; Klaassen, 1969; Hart, Guarino, and Adamson, 1969; Redinger et al, 1973). It is possible that this choleretic effect may have contributed to the gallstone formation. Thus the choleretic agent, sodium dehydrocholate, induces cholesterol gallstone formation in mice (Besançon, Marche, Souchard, and Debray, 1965; Tepperman and Weiner, 1968). The mechanism of this phenomenon remains unclear (Besançon, Marche, and Parrot, 1970; Besançon, 1972). It has been postulated that cholic acid interferes with the metabolism of cholesterol (Besançon, 1972). Another explanation is that gallbladder distension occurs and as a result there is both an increase in the absorbing area and an inflammatory reaction. This in turn may lead to concentrations of large volumes of bile together with the selective reabsorption of bile salts (Tepperman and Weiner, 1968). However, gallstone formation in hamsters is not accompanied by any gallbladder changes (Besançon, 1972). At present there is insufficient information concerning the effect of phenobarbital on bile flow in the hamster.

Phenobarbital increases cholesterol synthesis in rats (Wada et al, 1967; Orrenius et al, 1969) and in hamsters (Jones and Armstrong, 1965; Schoenfield et al, 1973). Probably as a result of the induction of the activity of the 3-hydroxy-3-methyl-glutamyl CoA reductase, which is the rate-limiting enzyme in cholesterol biosynthesis (Wade et al, 1967; Shefer et al, 1972; Schoenfield et al, 1973). It has been suggested that phenobarbital may also enhance the metabolism of cholesterol to bile salts because of the induction of the 7 alpha-hydroxylase, which is the rate-limiting enzyme in this transformation (Redinger and Small, 1973; Jones and Armstrong, 1965). However, in rats choleresis induced by phenobarbital (Roberts and Plaa, 1967) is not accompanied by an increase in the synthesis and excretory capacity for bile salts (Berthelot, Erlinger, Dhumeaux, and Preaux, 1970; Paumgartner, Sauter, Schwarz, and Herz, 1973). In man, phenobarbital results in a reduction of the bile salt pool size (Earnest, 1972). Moreover, the increased activity of 7 alpha-hydroxylase, reported in rats (Wada et al, 1968) and hamsters (Schoenfield et al, 1973), has been denied by others (Einarsson and Johansson, 1968; Shefer et al, 1972).

It is important to stress the differences in the response to phenobarbital depending upon the dose used and the species studied (Brodie, Gillette, and La Du, 1958; Quinn, Axelrod, and Brodie, 1958; Remmer, 1969, 1970). Low doses of the drug are associated with an increase in 7 alpha-hydroxylation in rats (Wada et al, 1968) but when higher doses are used the enhancement does not occur (Einarsson and Johansson, 1968; Shefer et al, 1972). In rhesus monkeys doses of $5 \mathrm{mg} / \mathrm{kg} /$ day result in a significant increase in total bile salts secretion, but when a large dose is used $(30 \mathrm{mg} / \mathrm{kg} /$ day $)$ animals become ill and there is a decrease in bile formation (Redinger and Small, 1973). Thus it is important to interpret our results in the light of the relatively large dose of phenobarbital which we administered-about eightfold larger than generally used and it is significant that an increase in bile salt synthetic capacity has been observed by Schoenfield et al (1973) using a very low dose regimen $(5 \mathrm{mg} / \mathrm{kg} /$ day $)$.

Our results suggest that on the rather high dose of phenobarbital we administered, 7 alpha-hydroxylation of cholesterol was not induced and may even have been depressed. In support of this concept is the observation that UDPGtase was not increased in phenobarbital-treated hamsters. The failure of the activity of the enzyme to increase probably reflects a failure to induce other hydroxylation-related enzymes. Enzymatic induction with phenobarbital occurs as a chain of events starting with deltaaminolevulinic synthetase (Marver, 1969), followed by cytochrome P-450, and the specific flavin enzyme for electron transport. All other enzymes not involved in hydroxylation increase at a later stage and to a lesser extent (Remmer and Merker, 1965; Remmer, 
1970). The UDPGtases are induced by phenobarbital after a period of latency during which hydroxylation enzymes increase (Orrenius, Ericsson, and Ernster, 1965; Orrenius, 1965). It is likely that UDPGtase induction is a secondary phenomenon consequent upon an enhanced formation of hydroxylated reaction products (Orrenius et al, 1969). Thus the increase will reflect enhancement of hydroxylationrelated enzymes and it was for this reason that we chose to measure this enzyme as an index of induction. It has been reported that rodents fed a carbohydrate diet underwent a reduction in these enzyme systems (Gillette, 1969) and this could be the explanation why the hamsters on the lithogenic diet showed lowered enzyme activity.

Phospholipid synthesis is increased after treatment with phenobarbital (Orrenius et al, 1969; Young et al, 1971). The peak of stimulation is reached on the fifth day after which it tends to return to normal (Japunžić et al, 1971). The very slight increase in biliary phospholipids which we found might therefore reflect some increase in its synthesis. The duration of phenobarbital administration may also influence the results. After administration of phenobarbital the induction of cytochrome $\mathrm{P}-450$ continues until a maximum at the third to fifth day after which a new steady state is achieved (Remmer, 1970). In prolonged administration of phenobarbital (five to 10 days) there is a stabilization of metabolic events and either microsomal enzymes (Remmer, 1970) or phospholipids synthesis (Japunžić et al, 1971) tend to return to normal levels. Because our studies were undertaken after 28 days of phenobarbital administration this may be another reason for the failure to find any increase in UDPGtase and a favourable change in bile composition.

These studies indicate the need for further evaluation of the effect of phenobarbital in the hamster liver. It will be necessary to follow the effects of different doses for varying duration on different diets. It is always dangerous to extrapolate from animal models of disease to the human situation, but the present investigation suggests that many variables will need to be considered before it can be established that phenobarbital will alter bile composition to favour dissolution of gallstones in man.

The authors gratefully acknowledge the advice and criticism of Miss J. Cullen. Dr Juan Lagarriga was in receipt of a British Council scholarship and a grant from the Mexican army. Ian A. D. Bouchier is in receipt of a grant from the Medical Research Council.

\section{References}

Admirand, W. H., and Small, D.M.(1968). The physicochemical basis of cholesterol gallstone formation in man. J. clin. Invest., 47, 1043-1052.

Bailey, N. T. J. (1959). Statistical Methods in Biology. The English University Press, London.

Bell, D. G., Whitney, B., and Dowling, R. H. (1972). Gallstone dissclution in man using chenodeoxycholic acid. Lancet, 2, 1213-1216.

Berthelot, P., Erlinger, S., Dhumeaux, D., and Preaux, A. M. (1970). Mechanism of phenobarbital induced hypercholeresis in the rat. Amer. J. Physiol., 219, 809-813.

Besançon, F. (1972). Gallstones: pathogenesis of the different forms, pathological and therapeutical similarities between chronic cholecystitis and atherosclerosis. R.C.rom. Gastro-ent., 4,145-158.

Besançon, F., Marche, C., and Parrot, J. (1970). Lithiase expérimentale par excès d'acide cholique chez la souris. Biol. et Gastroent. 2, 147-160.

Besançon, F., Marche, C., Souchard, M., and Debray, C. (1965). Lithiase vésiculaire déterminée par le dehydrocholate chez la souris. C.R. Soc. Biol., 159, 2333-2337.

Black, M., Billing, B. H., and Heirwegh, K. P. M. (1970). Determination of bilirubin UDP-Glucuronyl transferase activity in needle-biopsy specimens of human liver. Clin. chim. Acta, 29, 27-35.

Bouchier, I. A. D. (1971a). Experimental cholelithiasis. Sci. Basis Med. Ann. Rev., pp. 232-243. The Athlone Press, London.

Bouchier, I. A. D. (1971b). Gallstone formation. Lancet, 1, 711-715.

Brodie, B. B., Gillette, J. R., and La Du, B. N. (1958). Enzymatic metabolism of drugs and other foreign compounds. Ann. Rev. Biochem., 27, 427-454.

Conney, A. H. (1967). Pharmacological implication of microsomal enzyme induction. Pharm. Rev., 19, 317-366.

Dam, H. (1971). Determinants of cholesterol cholelithiasis in man and animals. Amer. J. Med., 51, 596-613.

Dam, H., and Christensen, F. (1962). Alimentary production of gallstones in hamsters. $Z$. Ernährungsw., 2, 154-159.

Danzinger, R. G., Hofmann, A. F., Schoenfield, L. J., and Thistle, J. L. (1971). Altered bile acid metabolism in patients with cholesterol cholelithiasis. (Abstr.) J. clin. Invest., 50, 24a.

Danzinger, R. G., Hofmann, A. F., Schoenfield, L. J., and Thistle, J. L. (1972). Dissolution of cholesterol gallstones by chenodeoxycholic acid. New Engl. J. Med., 286, 1-8.

Earnest, D. L. (1972). The effect of phenobarbital on pruritus and bile salt kinetics in patients with biliary cirrhosis and elevated serum bile salt concentration. In Bile Acids in Human Diseases, edited by P. Back, and W. Gerok, pp. 145-151. Schattauer, Stuttgart and New York.

Einarsson, K., and Johansson, G. (1968). Effect of phenobarbital on the conversion of cholesterol to taurocholic acid. Europ. $J$. Biochem., 6, 293-298.

Folch, J., Lees, M., and Sloane-Stanley, G. H. (1957). A simple method for the isolation and purification of total lipides from animal tissues. J. biol. Chem., 226, 497-509.

Fouts, J. R., and Gram, T. E. (1969). The metabolism of drugs by subfractions of hepatic microsomes: the case for microsomal heterogeneity. In Microsomes and Drug Oxidations, edited by J. R. Gillette, A. H. Conney, G. J. Cosmides, R. W. Estabrook J. R. Fouts, and G. J. Mannering, pp. 81-91. Academic Press, New York and London.

Gillette, J. R. (1969). Microsomes and drug metabolism. In Microsomes and Drug Oxidations, edited by J. R. Gillette, A. H. Conney, G. J. Cosmides, R. W. Estabrook, J. R. Fouts, and G. J. Mannering, pp. 215. Academic Press, New York and London.

Grundy, S. M., Metzger, A. L., and Adler, R. D. (1972). Mechanisms of lithogenic bile formation in American Indian women with cholesterol gallstones. J. clin. Invest., 51, 3026-3043.

Hart, L. G., Guarino, A. M., and Adamson, R. H. (1969). Effects of phenobarbital on biliary excretion of organic acids in male and female rats. Amer. J. Physiol., 217, 46-52.

Iwata, T., and Yamasaki, K. (1964). Enzymatic determination and thin-layer chromatography acids of bile salts in blood. J. Biochem. (Tokyo), 56, 424-431.

Japunžić, I., Mimić-oka, J., and Japundzic, M. (1971). Rat liver lipids during prolonged administration of phenobarbital. (Croatian), Acta med. iugosl., 25, 3-9.

Jones, A. L., and Armstrong, D. T. (1965). Increased cholesterol biosynthesis following phenobarbital induced hypertrophy of agranular endoplasmic reticulum in liver. Proc. Soc. exp. Biol. (N.Y.), 119, 1136-1139.

King, E. J. (1932). The colorimetric determination of phosphorus. Biochem. J., 26, 292-297. 
Klaassen, C. D. (1969). Biliary flow after microsomal enzyme induction. J. Pharmacol. exp. Ther., 168, 218-223.

Marver, H. S. (1969). The role of heme in the synthesis and repression of microsomal protein. In Microsomes and Drug Oxidations, edited by J. Gillette, A. H. Conney, G. S. Cosmides, R. W. Estabrook, J. R. Fouts, and G. J. Mannering, pp. 495-502. Academic Press, New York and London.

Nicolau, G., Shefer, S., Salen, G., and Mosbach, E. H. (1973). Hepatic 3-hydroxy-3-methylglutamyl CoA (HMG CoA) reductase and cholesterol $7 \alpha$ hydroxylase in man. (Abstr) Gastroenterology, 64, 887.

Orrenius, S. (1965). On the mechanism of drug hydroxylation in rat liver microsomes. J. Cell Biol., 26, 713-723.

Orrenius, S., Das, M., and Gnosspelius, Y. (1969). Overall biochemical effects of drug induction on the liver microsomes. In Microsomes and Drug Oxidations, edited by J. R. Gillette, A. H. Conney, G. J. Cosmides, R. W. Estabrook, J. R. Fouts, and G. J. Mannering, pp. 251-277. Academic Press, New York and London.

Orrenius, S., Ericsson, J. L. E., and Ernster, L. (1965). Phenobarbitalinduced synthesis of the microsomal drug metabolizing enzyme system and its relationship to the proliferation of endoplasmic membranes: a morphological and biochemical study J. Cell Biol., 25, 627-639.

Paumgartner, G., Sauter, K., Schwarz, H. P., and Herz, R. (1973). Hepatic excretory transport maximum for free conjugated. cholate in the rat: effect of phenobarbital. Hepatologie, 1, 217.

Plaa, G. L. (1968). Phenobarbitone and biliary excretion. Lancet, 2, 1348.

Quinn, G. P., Axelrod, J., and Brodie, B. B. (1958). Species, strain and sex differences in metabolism of hexobarbitone, aminopyrine, antipyrine and aniline. Biochem. Pharmacol., 1, 152-158.

Redinger, R. N., and Small, D. M. (1973). Primate biliary physiology. VIII. The effect of phenobarbital upon bile salt synthesis and pool size, biliary lipid secretion, and bile composition. J. clin. Invest., 52, 161-172.
Remmer, H. (1969). Induction of drug metabolizing enzymes in different animal species. Proc. europ. Soc. Study Drug Toxicity, 11, 14-24.

Remmer, H. (1970). The role of the liver in drug metabolism. Amer. J. Med., 49, 617-628.

Remmer, H., and Merker, H. J. (1965). Effect of drugs on the formation of smooth endoplasmic reticulum and drug metabolizing enzymes. Ann. N.Y. Acad. Sci., 123, 79-97.

Roberts, R. J., and Plaa, G. L. (1967). Effect of phenobarbital on the excretion of an exogenous bilirubin load. Biochem. Pharmacol., $16,827-835$.

Schoenfield, L. J., Rupprecht, R., and Bonorris, G. G. (1973). Induced alterations of bile acid and cholesterol synthesis in hamsters' liver. (Abstr.) Gastroenterology, 64, 892.

Shefer, S., Hauser, S., and Mosbach, E. H. (1972). Stimulation of cholesterol $7 \alpha$ hydroxylase by phenobarbital in two strains of rats. J. Lipid Res., 13, 69-70.

Tepperman, J., and Weiner, M. (1968). Experimental gallstones: an adventure in biological geology. Yale J. Biol. Med., 41, 107-118.

Vlahcevic, Z. R., Bell, C. C., Jr., Buhac, I., Farrar, J. T., and Swell, L. (1970). Diminished bile acid pool size in patients with gallstones. Gastroenterology, 59, 165-173.

Wada, F.. Hirata, K., Nakao, K., and Sakamoto,Y. (1968). Participation of P-450 in the $7 \alpha$ hydroxylation of cholesterol. J. Biochem. (Tokyo), 64, 415-417.

Wada, F., Hirata, K., and Sakamoto, Y. (1967). Relation of cholesterol synthesis and NADPH oxidation by microsomal electron transport system involving P-450. Biochim. biophys. Acta (Amst.), 143, 273-275.

Young, D. L., Powell, G., and McMillan, W. O. (1971). Phenobarbital induced alteration in phosphatidylcholine and triglyceride synthesis in hepatic endoplasmic reticulum. J. Lipid Res., 12, $1-8$.

Zlatkis, A. Zak, B., and Boyle, A.J. (1953). A new method for the direct determination of serum cholesterol. J. Lab. clin. Med., 41, 486-492. 